\title{
ТЕОРЕТИЧНІ ПІДХОДИ ДО ВИВЧЕННЯ СТАВЛЕННЯ ДО МОВИ
}

\author{
МАРІЯ МУЗИКА \\ Інститут мовознавства імені О.О. Потебні НАН України, Київ - Україна \\ jasum@ukr.net, ORCID: 0000-0002-9421-3140 \\ TEORETYCZNE PODEJŚCIE \\ DO STUDIÓW POSTAWY JĘZYKOWEJ
}

\begin{abstract}
MARIA MUZYKA
Instytut Językoznawstwa im. O.O. Potebni Narodowej Akademii Nauk Ukrainy, Kijów - Ukraina
\end{abstract}

STRESZCZENIE. Artykuł analizuje literaturę naukową dotyczącą badań w zakresie kształtowania postawy językowej, a także poglądy dydaktyków w kwestii socjolingwistycznej wykładni pojęcia postawy językowej. Wytyczono kluczowe kierunki badawcze w zakresie budowania postawy językowej oraz podkreślono szczególną wagę zgromadzonej wiedzy w przedmiotowej kwestii oraz aspekty badań w zakresie kształtowania postawy językowej w nauce ukraińskiej. Zbadanie kwestii kształtowania postawy językowej jest poważnym tematem współczesnego dyskursu naukowego, gdyż język pełni swoje społeczno-kulturowe funkcje. Znajomość postawy językowej umożliwia podjęcie skutecznych działań w zakresie planowania polityki językowej oraz kształtowania tożsamości nosicieli języka. Postawa językowa w życiu społecznym pozwala zarówno oceniać stopień lojalności wobec konkretnego języka, jak i wnioskować o funkcjach, które język pełni w społeczeństwie. Jest ona instrumentem pozwalającym zbudować efektywną politykę językową, wskazać na językowe utożsamienie nosiciela i wywieść wnioski o reputacji i stopniu poszanowania języka.

Słowa kluczowe: język, postawy językowe, socjolingwistyka, polityka językowa, tożsamość językowa, poszanowanie języka, lojalność językowa 


\title{
THEORETICAL APPROACHES TO LANGUAGE ATTITUDE STUDIES
}

\author{
MARIIA MUZYKA \\ O.O. Potebnia Institute of Linguistics of the National Academy of Science \\ of Ukraine, Kyiv - Ukraine
}

\begin{abstract}
This article focuses on the analysis of the scientific literature on investigating language attitude, theoretical approaches to the language attitude analyzed, the core paradigms of investigation connected to studying and distinguishing of language attitude presented, as well as the importance of data gathered regarding language attitudes and the specific nature of the language attitude studies in Ukraine that are analyzed. Studying language attitudes is popular, as the language which is investigated has numerous sociocultural functions, and knowledge of language attitudes helps to achieve success in language policy planning. Moreover, influences on linguistic personality and language attitudes allow evaluation not only of the loyalty to a particular language, but also the functional value of each of these. Language attitude is an instrument which allows successful language policy to be constructed, and also informs about the language identification of speaker, as well as about language status and prestige.
\end{abstract}

Keywords: language, language attitude, sociolinguistics, language policy, linguistic personality, prestige of language, language loyalty

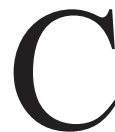

оціолінгвістичні дослідження є реакцією на виклики часу, аналізують взаємодію мов, особливості мовних ситуацій, причинно-наслідкові зв'язки між мовою та державою, мовою та ідеологією, мовою та нацією, мовою та політикою, мовою та релігією [Лабов 1970: 30-87]. До спектру проблем, які порушує соціолінгвістика, належить зокрема аналіз ставлення до мови.

Актуальність дослідження ставлення до мови зумовлена тим, що мова, яка підпадає під вивчення, виконує чимало соціокультурних функцій, а знання про ставлення до мови дозволяють досягти успіху при плануванні мовної політики та впливати на мовну особистість, так само як оцінити статус мови та їі значимість для окремої нації. Особливо актуальними такі дослідження є для тих країн, де активного вжитку набувають дві й більше мов, оскільки ставлення до мови дозволяє оцінити не тільки лояльність щодо певної мови, але й функціональне навантаження кожної з них.

Метою нашого дослідження є здійснити аналіз теоретичних підходів до вивчення соціолінгвістичної категорії ставлення до мови та описати теоретичну основу досліджень, пов'язаних з вивченням ставлення до мови.

До 1960-х років ставлення до мови не розглядалось як категорія соціолінгвістики, оскільки бехевіористичний підхід розглядав мову як поведінку, 
а не як когнітивну чи ментальну діяльність. Поведінкова теорія стверджувала, що ставлення є реакцією людей на соціальні ситуації [Фасольд 1984: 147]. Д. Едвардс визначає ставлення як схильність реагувати сприятливо або несприятливо на клас об'єктів [Едвардс 1985: 279]. Ця диспозиція складається 3 трьох компонентів: думка (когнітивний елемент), почуття (афективний компонент) та предиспозиція дії (поведінковий компонент). За такого підходу ставлення отримало наступні характеристики:

Концепт ставлення $є$ гіпотетичним. Це психологічний конструкт ставлення не можна визначити прямо, його можна отримати на основі аналізу суджень [де Клерк та Бош 1993: 209]. Відповідно, ставлення за такого підходу - це абстракція, яку не можна прямо передбачити [Оппенгейм 1982: 39].

1. Ставлення має оцінну природу. Як демонструє більшість визначень, ставлення несе в собі оцінку явища, позитивну чи негативну, це дозволяє розділити ставлення на добре чи погане, шкідливе чи вигідне, приємне чи неприємне, прихильне чи несхвальне [Айзен 2001: 31].

2. Ставлення - це оцінні реакції завжди звернені до об'єкта, щодо якого вони викликані.

3. Ставлення формується на основі досвіду і корегується набутими знаннями.

4. Ставлення породжує дію. Дослідники наголошують на наявності зв'язку між поведінкою та ставленням, деякі стверджують, що ставлення знаходиться в диспозиції до поведінки, опосередковуючи різницю між стимулом і викликаною реакцією [Фезольд 1984], тобто, якщо зв'язок між ними втрачено, то це не є ставлення [Іоаніс 2014: 98].

Ментальний же погляд на ставлення до мови був визначений Л. Вільямсом. Дотримуючись цього підходу, Де Клерк і Бош визначали ставлення до мови як гіпотетичний конструкт, який людина отримує через досвід та який диктує їй алгоритм дій у певних життєвих ситуаціях, питаннях, щодо певних об’єктів тощо [де Клерк та Бош 1993: 209].

Вивчення білінгвізму породило зацікавлення до ставлення до мови. Так, зокрема, у дослідженнях У. Ламберта сфокусовано увагу на можливості змінити ставлення до мови через запровадження нових принципів викладання [Ламберт 1967]. Іншу методологію представив Р. Фезольд [Фезольд 1984], яка полягала в оцінці мовлення двох хлопців через перегляд відео, розмови афроамериканця та „білого” хлопця (американця), згідно з дослідженням, мовлення „білого” хлопця було накладено на мовлення афроамериканця і навпаки, проте учасники надали свою прихильність саме мовленню „білого” хлопця, керуючись стереотипними уявленнями та загальноприйнятим ставленням до мови „білого” та афроамериканця. Такі експерименти свідчили про відсутність об' єктивізму в оцінках мовлення, а дані, які вдалось зібрати, були не об'єктивні, бо образ людини формується не тільки на підставі почутого 
чи побаченого, але і у результаті накладання тісї інформації, яка міститься в нашій пам'яті.

За У. Ламбертом, ставлення до мови складається з трьох компонентів: когнітивного, афективного та конативного [Ламберт 1967]. Когнітивний компонент належить до структури вірувань індивіда, афективний - до емоційних реакцій і конативний (поведінковий) компонент осягає тенденцію щодо певного виду поводження відповідно до поглядів [Гарднер 2007]. Ці три компоненти впливають на ставлення індивіда до мови та містять в собі знання не тільки про мовні вподобання, але й про мовну готовність, досвід і уявлення. Іншими словами, ставлення до мови - це внутрішній стан готовності, а не видимі відповіді.

В огляді досліджень ставлення до мови Р. Агейїс і Дж. Фішман визначили три напрямки, які охоплюють дослідження ставлення до мови: а) дослідження, які скеровані на оцінку мовно орієнтованого ставлення (languageoriented attitudes); б) дослідження, до сфери зацікавлень яких входить суспільне значення мови (social significance of languages) та мовні різновиди, що дозволяють простежити стереотипні уявлення групи (group stereotyped impressions); в) дослідження, які стосуються мовної поведінки (language related behaviors), такі як вивчення мови, вибір мови, іiі використання/вживання, зміцнення iï статусу та мовне планування [Агейїс, Фішман 1970: 137-157].

Ці дослідницькі напрямки, що з'явилися в 1970-х роках, розширились в останні десятиліття. Сфера „вивчення мови” отримала вражаючий розвиток, ставши одним з основних напрямків дослідження ставлення до мови. Взявши за основу класифікацію Р. Агейї і Дж. Фішман і аналізуючи сучасні тенденції щодо вивчення ставлення до мови, Марія Аделіна Іанос у своєму дослідженні, присвяченому аналізу ставлення до мови у мультилінгвальному та мультикультурному контексті, аналізуючи ставлення до мови автохтонних та студентів-іммігрантів Каталонії, виділяє чотири головні категорії дослідження ставлення до мови, а саме:

1. Парадигма оцінки мови (The language evaluation paradigm), сфокусована на ставленні до мови, де мова розглядається як засіб. Такі дослідження були проведені У.В. Шарпом та В. Бейкером. Методологічно пряме вимірювання за допомогою анкети $є$ найбільш характерним для цього напряму вивчення ставлення до мови.

2. Парадигма оцінки мовця, яка бере свій початок з досліджень У. Ламберта та його соратників у Канаді та стосується аналізу ставлення мовця, який говорить певною мовою чи мовним різновидом. Ця парадигма досліджень також має свою техніку непрямого дослідження - це техніка підбору масок „the matched-guise technique".

3. Парадигма вивчення мови фокусується на вивченні мови як феномену та бере свій початок з досліджень Р. Гарднера, проведених у Канаді. 
Ставлення до вивчення мови, до ситуації навчання та до мовної спільноти розглядаються з погляду мотивації мовця. Для таких досліджень науковець використовує анкету.

4. Дослідження, що розглядають ставлення до мови через аналіз мовної поведінки, тобто увага скерована на те, як використовується мова та способи підтримки мови [Іоаніс 2014: 133-136].

Ставлення до мови дозволяє оцінити ситуацію тут і зараз та змоделювати зміни, які можуть відбутись в майбутньому. Умовно ставлення до мови аналізують у таких контекстах, як, наприклад, коли поряд активно функціонують дві чи більше офіційно визнані мови: ситуація у Каталонії, Країні Басків, Валенсії, Уельсі, Бельгії, Південній Африці, Гонконгу. Або ж визначення ставлення до поширеної на території мови, як наприклад, аналіз ставлення до англійської мови як lingua franca, - такі дослідження були проведені в Угорщині.

Вибір категорії дослідження зазвичай диктується обставинами та мовною ситуацією, оскільки дослідники здійснюють аналіз ставлення до мови в різних мовних спільнотах та ставлять перед собою різні цілі. Проаналізувавши запропоновані напрями, вважаємо найбільш продуктивним для нашого дослідження напрям, який запропонував Марія Аделіна Іанос, - розглянути ставлення до мови через аналіз мовної поведінки, тобто зосередити увагу на тому, як використовується мова та порушується питання підтримки мови. Діаграма соціолінгвістичних параметрів мовної поведінки виявляється у двох вимірах - через мовну практику (повсякденне спілкування, вибір мови освіти, вибір мови інформації, рівень мовної компетенції тощо) та через ставлення до мови (рідна мова, мова як суспільна цінність, мова як символ, етнічна мова, престижна мова, мова як ознака індивідуалізації особи тощо). Таке дослідження не обмежує нас у виборі методики та дозволяє нам розшити спектр нашого аналізу, бо мовна поведінка в соціолінгвістичному вимірі - це не тільки мовна практика, що часто зумовлена соціальним чи мовним середовищем і відповідно є рольовим вибором мови, а й мовна ідентифікація, що виявляється через ставлення до мови, найпоширенішими виявами якого $\epsilon$ етномовна самоідентифікація та мовна орієнтація, що зазвичай $€$ визначальними при виборі мови як рідної. з погляду соціолінгвістики мовна поведінка особистості нерозривно пов'язана з соціальними чинниками, що впливають на вибір певного мовного коду та відображає ставлення до мови як засобу національного самовизначення та засобу спілкування, у мовній поведінці індивіда поєднані емотивні та раціональні аспекти [Михальчук 2014: 36].

На теренах України перші соціолінгвістичні дослідження активно почались $з$ проголошенням Незалежності, оскільки до цього моменту мовна політика була скерована на нівелювання статусу української мови, українська мова не заперечувалась, але сфери іiі використання були обмежені навмисно насадженою російською мовою, а будь-яка критика ситуації вважалася за- 
йвою та гостро заперечувалась владою. Перші соціолінгвістичні дослідження в Україні були зосереджені на аналізі загальної мовної політики та мови емігрантів, вже 3 часом соціолінгвісти стали утверджувати статус української мови в межах України. Ще в 1960-х роках праця Інтернаціоналізм чи русифікаиія I. Дзюби вперше правдиво представила проблему білінгвізму: це перша робота, присвячена вивченню реальної мовної ситуації країні, що порушує питання насильної русифікації, спростовує догму про «гармонійну» українсько-російську двомовність. Праця містить аналіз взаємозв'язків мови, культури та національної свідомості, а також порушує проблему згубного впливу денаціоналізації на моральний стан суспільства.

У період незалежності України змінюються акценти в дослідженнях, уперше порушуються проблеми досвіду мовної політики в контексті державотворення, зокрема в працях О. Данилевської Мовна політика Центральної ради, Гетьманату та Директорії УНР, О. Ткаченка у праці Украӥнська мова $i$ мовне життя світу, де наголошується на необхідності вироблення мовної стійкості з метою мовного самоствердження народу. Р. Кісь розглядає мову як діяльність, а не замкнену систему, сповідуючи теорію О. Потебні про єдність мови, культури та ідентичності [Масенко 2010: 33-37]. В. Чемес провів серію анкетувань у різних соціальних групах, метою яких $\epsilon$ виявлення оцінних характеристик української мови, мотивація мовної поведінки в умовах білінгвізму, самооцінки рівня володіння українською мовою, співвіднесені 3 виявленням реального ступеня компетентності анкетованих щодо показових сфер ненормативності сучасного українського мовлення [Масенко 2011: 26]. Ситуації полілінгвізму була присвячена дисертація О. Палінської, яка досліджувала функціонування трьох мов - української, німецької та польської на території Буковини [Масенко 2011: 26]. Досліджень ставлення до мови в українській соціолінгвістиці небагато, спорадично до питання ставлення до мови звертались Л. Масенко, Б. Ажнюк, Л. Андрієнко, О. Михальчук, Т. Фудерер, Г. Яворська, О. Данилевська, В. Чемес та інші.

Л. Масенко зауважує, що ставлення соціуму до мови $є$ надзвичайно важливим стимулом збереження або, навпаки, зміни мовної ситуації [Масенко 2004: 107] та зауважує, що однією з оцінних характеристик, що грунтується на ставленні мовців, є престиж мови. Г. Залізняк та Л. Масенко в кількох соціолінгвістичних дослідженнях простежують кореляцію між рівнем престижності та вибором мови. На думку О. Михальчук, ставлення до мови виявляється через мовну самоідентифікацію та вибір мови в певних ситуаціях [Михальчук 2011: 323-331].

Перспективою нашого дослідження $є$ визначення ставлення до мови через аналіз мовної поведінки українця, мотивації у виборі мови, визначення статусу української мови, іiї престижу. У соціолінгвістиці мовна поведінка розкриває ставлення до мови як основний інструмент для реалізації комуні- 
кативних, психологічних, культурних потреб відповідно до соціальної ситуації і внутрішніх установок щодо вибору мовного коду, вказує на зв'язок між мовною ідентичністю та прагматичним вибором мови. Ми погоджуємось із думкою дослідників про те, що ставлення до мови - це проекція нашої пам'яті на основі здобутого досвіду, це гіпотетичний конструкт, який можна вибудувати на основі зібраних відповідей, це інструмент, який дозволяє будувати успішну мовну політику та інформує про мовну ідентифікацію мовця, так само як і про статус та престиж мови, щодо якої здійснюється дослідження.

На сьогодні існують різноманітні підходи та вектори дослідження ставлення до мови, які зумовлені конкретною мовною ситуацією та інтенціями дослідника. Проте актуальність та ефективність таких досліджень, що передбачають збір інформації про ставлення до мови, корелює з питаннями мовної безпеки та мовної поведінки, а їхня цінність для соціолінгвістики беззаперечна.

\section{Список використаної літератури}

Масенко Л., Нариси з соиіолінгвістики, Київ: Києво-Могилянська академія, 2010.

Михальчук О., „Мовна поведінка” як категорія украӥнської сочіолінгвістики, [в:] „Мова і суспільство", 2014, вип. 5, с. 28-39.

Михальчук О., Мова як символ в етнічній та мовній свідомості: соиіолінгвістичні параметри, [в:] „Життя - У слові: Збірник наукових праць на пошану академіка В.М. Русанівського", Київ: Видавничий дім Дмитра Бураго, 2011, с. 323-333.

Agheyisi R., Fishman J., Language attitude studies: A brief survey of methodological approaches, [в:] „Anthropological Linguistics”, 1970, nr 12 (5), p. 137-157.

Ajzen I., Nature and operation of attitudes, [in:] Електронний ресурс: http://friedkin. faculty. soc.ucsb.edu/Syllabi/Soc147/Week2Reading.pdf (01.01.2013).

Edwards J., Language, society and identity, Oxford, UK: Blackwell, 1985.

Fasold R., The sociolinguistic of society, Oxford, UK: Blackwell, 1984.

Gardner R., Integrative motivation and second language acquisition, [in:] "Motivation and second language acquisition”, eds. Z. Dörnyei, R. Schmidt, Honolulu, HI: University of Hawaii Press, 2007, p. 1-21.

Gardner R., Social psychology and second language learning: The role of attitudes and motivation, London, UK: Edward Arnold, 1985.

Ianos M.A., Language attitudes in a multilingual and multicultural context. The case of autochthonous and immigrant students in Catalonia, Universitat de Lleida. Departament de Pedagogia i Psicologia, 2014, p. 475.

de Klerk V. and Bosch B., English in South Africa: The Eastern Cape perspective, 1993, [in:] English World-Wide 14:2, p. 209-229.

Labov W., The Study of Language in its Social Context, [in:] „Studium Generale”, 1970, nr 23, p. $30-87$. 
Lambert W., A social psychology of bilingualism, [in:] Journal of Social Issues, 1967, nr 23, p. 91-109.

Oppenheim B., An exercise in attitude measurement, [in:] Social Psychology: A Practical Manual, eds. G.M. Breakwell, H. Foot, R. Gilmour, London, UK: Macmillan Press, 1982, p. 38-56.

\section{Spysok vykorystanoi literatury (References)}

Masenko L., Narysy z sotsiolinhvistyky [Essays on sociolinguistics], Kyiv: Kyievo-Mohylianska akademiia, 2010.

Mykhalchuk O., Mova iak symvol v etnichnii ta movnii svidomosti: sotsiolinhvistychni parametry (Language as a symbol of aesthetic and linguistic consciousness: sociolinguistics parameters), [v:] „Zhyttia - u slovi: Zbirnyk naukovykh prats na poshanu akademika V.M. Rusanivskoho", Kyiv, Vydavnychyi dim Dmytra Buraho, 2011, s. 323-333.

Mykhalchuk O., ,,Movna povedinka” iak katehoriia ukrainskoi sotsiolinhvistyky [,, Language behavior” as a category of Ukrainian sociolinguistics], [v:] „Mova i suspilstvo”, 2014, vyp. 5, s. 28-39.

Agheyisi R., Fishman J., Language attitude studies: A brief survey of methodological approaches, 1970, [v:] "Anthropological Linguistics”, 1970, nr 12 (5), p. 137-157.

Ajzen I., Nature and operation of attitudes, [v:] Elektronnyi resurs: http://friedkin.faculty. soc. ucsb.edu/Syllabi/Soc147/Week2Reading.pdf (01.01.2013).

de Klerk V., Bosch B., English in South Africa: The Eastern Cape perspective, 1993, [in:] English World-Wide 14:2, 209-229.

Edwards J., Language, society and identity, Oxford, UK: Blackwell, 1985.

Ianos M.A., Language attitudes in a multilingual and multicultural context. The case of autochthonous and immigrant students in Catalonia, Universitat de Lleida. Departament de Pedagogia i Psicologia, 2014.

Fasold R., The sociolinguistic of society, Oxford, UK: Blackwell, 1984.

Gardner R., Integrative motivation and second language acquisition, [in:] Motivation and second language acquisition, eds. Z. Dörnyei, R. Schmidt, Honolulu, HI: University of Hawaii Press, 2007, p. 1-21.

Gardner R., Social psychology and second language learning: The role of attitudes and motivation, London, UK: Edward Arnold, 1985.

Labov W., The Study of Language in its Social Context, [in:] "Studium Generale”, 1970, nr 23, p. 30-87.

Lambert W., A social psychology of bilingualism, [in:] “Journal of Social Issues”, 1967, nr 23, p. $91-109$.

Oppenheim B., An exercise in attitude measurement, [in:] Social Psychology: A Practical Manual, eds. G.M. Breakwell, H. Foot, R. Gilmour, London, UK: Macmillan Press, 1982, p. 38-56. 